\title{
Handbook of Research on Environmental Taxation
}

Edited by

Janet E. Milne

Professor of Law and Director of the Environmental Tax Policy Institute, Vermont Law School, USA

Mikael Skou Andersen

Professor, Department of Environmental Science, Aarhus University, Denmark and European Environment Agency

\section{Edward Elgar}

Cheltenham, UK・ Northampton, MA, USA 
(C) The Editors and Contributors Severally 2012

All rights reserved. No part of this publication may be reproduced, stored in a retrieval system or transmitted in any form or by any means, electronic, mechanical or photocopying, recording, or otherwise without the prior permission of the publisher.

Published by

Edward Elgar Publishing Limited

The Lypiatts

15 Lansdown Road

Cheltenham

Glos GL50 2JA

$\mathrm{UK}$

Edward Elgar Publishing, Inc.

William Pratt House

9 Dewey Court

Northampton

Massachusetts 01060

USA

A catalogue record for this book

is available from the British Library

Library of Congress Control Number: 2012939922

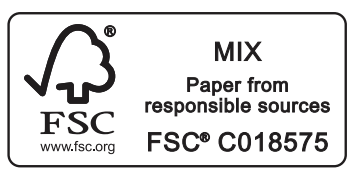

ISBN 9781848449978

Typeset by Servis Filmsetting Ltd, Stockport, Cheshire

Printed and bound by MPG Books Group, UK 


\section{Contents}

List of contributors vii

Acknowledgments $\quad \mathrm{x}$

List of abbreviations $\quad$ xi

1 This book's approach to environmental taxation 1 Janet E. Milne

\section{PART I CONCEPTUAL FOUNDATIONS}

2 Introduction to environmental taxation concepts and research 15 Janet E. Milne and Mikael Skou Andersen

3 Economic principles of environmental fiscal reform 33 Jean-Philippe Barde and Olivier Godard

4 Legal authority to enact environmental taxes Michael Rodi and Hope Ashiabor (contributing author)

\section{PART II DESIGN}

5 Design options and their rationales 85 Pedro M. Herrera Molina

6 Earmarking revenues from environmentally related taxes Claudia Dias Soares

7 Designing environmental taxes in countries in transition: a case study of Vietnam Michael Rodi, Kai Schlegelmilch and Michael Mehling

8 Externality research Philipp Preiss

\section{PART III ACCEPTANCE}

9 Regressivity of environmental taxation: myth or reality?

\section{Katri Kosonen}

10 The political acceptability of carbon taxes: lessons from British Columbia Mark Jaccard

11 Gaining intergovernmental acceptance: legal rules protecting trade Birgitte Egelund Olsen

12 The double dividend debate William K. Jaeger

13 The political economy of environmental taxation Nils Axel Braathen 


\section{PART IV IMPLEMENTATION}

14 Multilevel governance: the implications of legal competences to collect, administer and regulate environmental tax instruments

Nathalie Chalifour, María Amparo Grau-Ruiz and Edoardo Traversa

15 Transaction costs of environmental taxation: the administrative burden Jan Pavel and Leoš Vitek

16 Structuring road transport taxes to capture externalities: a critical analysis of approaches

Teresa Palmer-Tous and Antoni Riera-Font

17 Environmental taxation in China: the greening of an emerging economy Yan $X u$

18 A review of selected databases on market-based instruments Hans Vos

\section{PART V IMPACT}

19 Decoupling: is there a separate contribution from environmental taxation? Adrian Muller, Asa Löfgren and Thomas Sterner

20 The role of environmental taxation in spurring technological change Herman Vollebergh

21 Impacts on competitiveness: what do we know from modeling?

Paul Ekins and Stefan Speck

\section{PART VI POLICY MIX}

22 The role of environmental taxation: economics and the law Michael Faure and Stefan E. Weishaar

23 Regulatory reform and development of environmental taxation: the case of carbon taxation and ecological tax reform in Finland

Rauno Sairinen

24 Bounded rationality in an imperfect world of regulations: what if individuals are not optimizing?

Helle Ørsted Nielsen

25 Global environmental taxes

Philippe Thalmann

\section{PART VII CONCLUSION}

26 The future agenda for environmental taxation research 


\section{Contributors}

Mikael Skou Andersen, Professor, Department of Environmental Science, Aarhus University, Denmark, currently with the European Environment Agency

Hope Ashiabor, Associate Professor of Law, Faculty of Business and Economics, Macquarie University, Australia

Jean-Philippe Barde, former Head of the OECD National Environmental Policies Division; Lecturer, SciencesPo Paris (Paris School of International Affairs), France

Nils Axel Braathen, Principal Administrator, Environment Directorate, OECD, France

Nathalie Chalifour, Associate Professor, Faculty of Law, University of Ottawa, Centre for Environmental Law and Global Sustainability, Canada

Paul Ekins, Professor of Resources and Environment Policy and Director, UCL Institute for Sustainable Resources, University College London, England

Michael Faure, Professor of Comparative and International Environmental Law, Maastricht University, and Professor of Comparative Private Law and Economics, Erasmus University Rotterdam, The Netherlands

Olivier Godard, Director of Research at CNRS, Economics Laboratory, École Polytechnique, France

María Amparo Grau-Ruiz, Associate Professor, Financial and Tax Law Department, Faculty of Law, Complutense University of Madrid, Spain

Pedro M. Herrera Molina, Full Professor of Tax Law, Spanish Open University (UNED), Spain

Mark Jaccard, Professor, School of Resource and Environmental Management, Simon Fraser University, Canada

William K. Jaeger, Professor, Department of Agricultural and Resource Economics, Oregon State University, United States

Katri Kosonen, Principal Administrator, Economist, DG TAXUD, European Commission, Belgium

Åsa Löfgren, Associate Professor, Department of Economics, University of Gothenburg, Sweden

Michael Mehling, President, Ecologic Institute, and Adjunct Professor, Georgetown University, United States

Janet E. Milne, Professor of Law and Director, Environmental Tax Policy Institute, Vermont Law School, United States 
Adrian Muller, Senior Researcher, Environmental Policy and Economics, Department of Environmental Systems Science, Swiss Institute of Institute of Technology Zurich, Switzerland

Helle Ørsted Nielsen, Senior scientist, Political Science, Department of Environmental Science, Aarhus University, Denmark

Birgitte Egelund Olsen, Professor and Director of Study, Master of Environmental and Energy Law, Department of Law, Aarhus University, Denmark

Teresa Palmer-Tous, Associate Professor, Department of Applied Economics, University of Balearic Islands, Spain

Jan Pavel, Associate Professor, Department of Public Finance, University of Economics, Czech Republic

Philipp Preiss, Head of the section Technology Assessment, Institute of Energy Economics and the Rational Use of Energy, Department of Technology Assessment and Environment, Universität Stuttgart, Germany

Antoni Riera-Font, Chair Professor in Applied Economics and Director of the Research, Economic Center University of Balearic Islands, Spain

Michael Rodi, Professor of Law, University of Greifswald, Faculty of Law, and Economics and Managing Director, Institute for Climate Protection, Energy and Mobility, Germany

Rauno Sairinen, Professor (environmental policy), University of Eastern Finland, Finland

Kai Schlegelmilch, Environmental Fiscal Expert, Federal Environment Agency (Umweltbundesamt), Germany.

Claudia Dias Soares, Professor of Law, Law School, Portuguese Catholic University, Portugal

Stefan Speck, Project Manager, Environmental Economics and Policies, Integrated Environmental Assessments Program, European Environment Agency, Denmark

Thomas Sterner, Professor, Department of Economics, University of Gothenburg, Sweden, currently Visiting Chief Economist, Environmental Defense Fund; former President of the European Association of Environmental and Resource Economists

Philippe Thalmann, Associate Professor, School of Architecture, Civil and Environmental Engineering, École Polytechnique Fédérale de Lausanne (EPFL), Switzerland

Edoardo Traversa, Professor of Tax Law, Faculty of Law, Catholic University of Louvain, Belgium

Leoš Vítek, Associate Professor, Department of Public Finance, University of Economics, Prague, Czech Republic

Herman Vollebergh, Senior Researcher, PBL Netherlands Environmental Assessment Agency, and Research Fellow, CentER and Tilburg Sustainability Center, Tilburg University, The Netherlands 
Hans Vos, independent; former Project Manager with the European Environment Agency, The Netherlands

Stefan E. Weishaar, Associate Professor of Law and Economics, Department of Law and Economics, Faculty of Law, University of Groningen, The Netherlands

Yan Xu, Assistant Professor, Faculty of Law, The Chinese University of Hong Kong, Hong Kong, China, and Senior Research Fellow, Taxation Law and Policy Research Institute, Monash University, Australia 